\title{
New benzophenone and quercetin galloyl glycosides from Psidium guajava $\mathbf{L}$.
}

\author{
Keiichi Matsuzaki • Rie Ishii • Kaori Kobiyama • \\ Susumu Kitanaka
}

Received: 28 October 2009/Accepted: 15 January 2010/Published online: 31 March 2010

(C) The Author(s) 2010. This article is published with open access at Springerlink.com

\begin{abstract}
New benzophenone and flavonol galloyl glycosides were isolated from an $80 \% \mathrm{MeOH}$ extract of Psidium guajava L. (Myrtaceae) together with five known quercetin glycosides. The structures of the novel glycosides were elucidated to be 2,4,6-trihydroxybenzophenone 4-O(6"-O-galloyl)- $\beta$-D-glucopyranoside (1, guavinoside A), 2,4,6-trihydroxy-3,5-dimethylbenzophenone $\quad 4-O-\left(6^{\prime \prime}-O-\right.$ galloyl)- $\beta$-D-glucopyranoside (2, guavinoside $\mathrm{B}$ ), and quercetin $3-O-\left(5^{\prime \prime}-O\right.$-galloyl)- $\alpha$-L-arabinofuranoside $\quad(3$, guavinoside C) by NMR, MS, UV, and IR spectroscopies. Isolated phenolic glycosides showed significant inhibitory activities against histamine release from rat peritoneal mast cells, and nitric oxide production from a murine macrophage-like cell line, RAW 264.7.
\end{abstract}

Keywords Psidium guajava L. · Benzophenone galloyl glycoside - Flavonol galloyl glycoside

\section{Introduction}

Psidium guajava (Myrtaceae) is a small medicinal tree that is native to South America. All parts of this tree, including fruits, leaves, bark, and roots, have been used for treating stomachache and diarrhea in many countries. Previous

K. Matsuzaki $\cdot$ K. Kobiyama $\cdot$ S. Kitanaka $(\bowtie)$

Research Unit of Pharmacognosy, College of Pharmacy,

Nihon University, 7-7-1 Narashinodai, Funabashi,

Chiba 274-8555, Japan

e-mail: kitanaka.susumu@nihon-u.ac.jp

R. Ishii

Saitama Institute of Public Health, Kami-Ohkubo,

Saitama 338-0824, Japan studies of this plant have led to the isolation of tannins $[1,2]$, tannins and other phenolic compounds [3], flavonol glycosides [4, 5], triterpenoids [6], terpenoids [7], and carotenoids [8]. It is well known that an extract of the leaves of $P$. guajava improves symptoms of allergic disease, and we are interested in small molecules from the leaves of $P$. guajava, other than tannins, and their potential anti-inflammatory activities.

In this investigation, two new benzophenone galloyl glycosides, guavinosides A (1) and B (2), and a quercetin galloyl glycoside, guavinoside C (3), were isolated from the leaves of $P$. guajava together with known quercetin glycosides (4-8). These structures of the novel glycosides were established through detailed analysis of their spectroscopic data and chemical evidence, and their inhibitory activities against histamine release from rat mast cells and nitric oxide (NO) from RAW 264.7 were also determined.

\section{Results and discussion}

Guavinoside A (1) was obtained as a yellow powder. The positive ion mode FAB-MS of $\mathbf{1}$ showed a quasimolecular ion peak at $m / z 545[\mathrm{M}+\mathrm{H}]^{+}$, and the molecular formula was determined to be $\mathrm{C}_{26} \mathrm{H}_{24} \mathrm{O}_{13}$ based on its high-resolution (HR)-FAB-MS (found 545.8418, calcd. 545.8413 for $\mathrm{C}_{26} \mathrm{H}_{25} \mathrm{O}_{13}$ ). In the IR spectrum, the strong absorbance at $1,700 \mathrm{~cm}^{-1}$ indicated the presence of conjugated carbonyl groups in $\mathbf{1}$. Acid hydrolysis of $\mathbf{1}$ furnished D-glucose which was identical with HPLC analysis, using an optical rotation (OR) detector. In the ${ }^{1} \mathrm{H}-\mathrm{NMR}$ spectrum of $\mathbf{1}$, two aromatic signals at $\delta_{\mathrm{H}} 6.11(2 \mathrm{H}, \mathrm{s})$ and $6.98,(2 \mathrm{H}, \mathrm{s})$ indicated the presence of two 1,3,4,5-tetrasubstituted phenyl groups, and the spin system of $\delta_{\mathrm{H}} 7.68(2 \mathrm{H}$, dd, $J=7.0,1.0 \mathrm{~Hz}), 7.46(2 \mathrm{H}, \mathrm{t}, J=7.0 \mathrm{~Hz})$, and $7.57(1 \mathrm{H}, \mathrm{t}$, 
$J=7.0 \mathrm{~Hz}$ ) showed the presence of a phenyl group. Additionally, an anomeric proton signal at $\delta_{\mathrm{H}} 4.86(1 \mathrm{H}, \mathrm{d}$, $J=7.6 \mathrm{~Hz}$ ) indicated that the glucose residue was in the $\beta$-form. Correlations in the ${ }^{1} \mathrm{H}-{ }^{1} \mathrm{H}-\mathrm{COSY}$ spectrum were observed from the anomeric proton to $\delta_{\mathrm{H}} 3.15(1 \mathrm{H}, \mathrm{m})$, $3.20(1 \mathrm{H}, \mathrm{m}), 3.50(1 \mathrm{H}, \mathrm{m}), 3.30(1 \mathrm{H}, \mathrm{m})$, and $4.39(2 \mathrm{H}, \mathrm{br}$ s) indicating the presence of $\beta$-glucose. The signal pattern in the aromatic region of the ${ }^{13} \mathrm{C}$-NMR spectrum indicated the presence of three aromatic rings. In addition, the ${ }^{13} \mathrm{C}$ NMR and DEPT spectra showed an anomeric carbon $\left(\delta_{\mathrm{C}}\right.$ $100.5)$, four oxymethines $\left(\delta_{\mathrm{C}} 73.0,76.1,68.9\right.$, and 73.6), an oxymethylene $\left(\delta_{\mathrm{C}} 62.5\right)$, and two carbonyl carbons $\left(\delta_{\mathrm{C}}\right.$ 165.7 and 195.3). All proton-carbon connectivities assigned by using HMQC experiments are summarized in Table 1. The HMBC correlations from $2^{\prime \prime \prime}, 6^{\prime \prime \prime}-\mathrm{H}\left(\delta_{\mathrm{H}} 6.98\right.$, $2 \mathrm{H}, \mathrm{s})$ to $\mathrm{C}-1^{\prime \prime \prime}\left(\delta_{\mathrm{C}} 119.2\right), \mathrm{C}-3^{\prime \prime \prime}, 5^{\prime \prime \prime}\left(\delta_{\mathrm{C}} 145.4\right), \mathrm{C}-4^{\prime \prime \prime}\left(\delta_{\mathrm{C}}\right.$ 138.4), and a carbonyl carbon $\left(\delta_{\mathrm{C}} 165.7\right)$ revealed the presence of a galloyl moiety. A phenyl proton signal at $\delta_{\mathrm{H}}$ $7.68\left(2 \mathrm{H}, \mathrm{dd}, J=7.0,1.0 \mathrm{~Hz}, 2^{\prime}, 6^{\prime}-\mathrm{H}\right)$ correlated with a carbonyl carbon signal at $\delta_{\mathrm{C}} 195.3$, and an aromatic proton at $\delta_{\mathrm{H}} 6.11(2 \mathrm{H}, \mathrm{s}, 3,5-\mathrm{H})$ correlated with $\mathrm{C}-4\left(\delta_{\mathrm{C}} 159.8\right)$ and the carbonyl carbon by weak ${ }^{4} J$ correlation. Furthermore, the anomeric proton signal correlated with $\mathrm{C}-4$. NOE enhancement was observed between the anomeric proton signal and the signal of $3,5-\mathrm{H}$. These data suggested that the aglycone of 1 was 2,4,6-trihydroxybenzophenone, and a sugar was attached at $\mathrm{C}-4$. The signal of $6^{\prime \prime}-\mathrm{H}$, however, was downfield shifted at $\delta_{\mathrm{H}} 4.39(2 \mathrm{H}$, br s), and correlated with the galloyl carbonyl carbon signal at $\delta_{\mathrm{C}} 165.7$ in the HMBC experiment. From these data, the structure of $\mathbf{1}$ was established to be 2,4,6-dihydroxybenzophenone 4-O-(6"$O$-galloyl)- $\beta$-D-glucopyranoside (Figs. 1, 2).

Guavinoside B (2) was obtained as a brownish solid. The negative ion mode FAB-MS of 2 showed quasimolecular ion peak at $\mathrm{m} / z, 571[\mathrm{M}-\mathrm{H}]^{-}$, and the molecular formula was determined to be $\mathrm{C}_{28} \mathrm{H}_{28} \mathrm{O}_{13}$ based on its HRFAB-MS (found 571.1474, calcd. 571.1451 for $\mathrm{C}_{28} \mathrm{H}_{27} \mathrm{O}_{13}$ ). The molecular weight was 28 mass units $\left(\mathrm{C}_{2} \mathrm{H}_{4}\right)$ greater than that of $\mathbf{1}$. The ${ }^{1} \mathrm{H}$ - and ${ }^{13} \mathrm{C}-\mathrm{NMR}$ spectra of $\mathbf{2}$ were very similar to those of $\mathbf{1}$ except for

Table $1{ }^{13} \mathrm{C}$ - and ${ }^{1} \mathrm{H}-\mathrm{NMR}$ spectral data of guavinosides A (1) and B (2)

\begin{tabular}{|c|c|c|c|c|}
\hline & \multicolumn{2}{|l|}{1} & \multicolumn{2}{|l|}{2} \\
\hline & $\delta_{\mathrm{C}}$ & $\delta_{\mathrm{H}}$ & $\delta_{\mathrm{C}}$ & $\delta_{\mathrm{H}}$ \\
\hline \multicolumn{5}{|l|}{ Aglycone } \\
\hline 1 & $108.9 \mathrm{~s}$ & & $113.0 \mathrm{~s}$ & \\
\hline 2,6 & $157.3 \mathrm{~s}$ & & $151.8 \mathrm{~s}$ & \\
\hline 3,5 & $94.9 \mathrm{~d}$ & $6.11(2 \mathrm{H}, \mathrm{s})$ & $110.8 \mathrm{~s}$ & \\
\hline 4 & $159.8 \mathrm{~s}$ & & $155.6 \mathrm{~s}$ & \\
\hline $1^{\prime}$ & $138.4 \mathrm{~s}$ & & $138.7 \mathrm{~s}$ & \\
\hline $2^{\prime}, 6^{\prime}$ & $128.7 \mathrm{~d}$ & $7.68(2 \mathrm{H}, \mathrm{dd}, J=7.0,1.0 \mathrm{~Hz})$ & $128.6 \mathrm{~d}$ & $7.65(2 \mathrm{H}, \mathrm{dd}, J=7.0,1.0 \mathrm{~Hz})$ \\
\hline $3^{\prime}, 5^{\prime}$ & $128.2 \mathrm{~d}$ & $7.46(2 \mathrm{H}, \mathrm{t}, J=7.0 \mathrm{~Hz})$ & $128.1 \mathrm{~d}$ & $7.45(2 \mathrm{H}, \mathrm{t}, J=7.0 \mathrm{~Hz})$ \\
\hline $4^{\prime}$ & $132.5 \mathrm{~d}$ & $7.57(1 \mathrm{H}, \mathrm{t}, J=7.0 \mathrm{~Hz})$ & $132.3 \mathrm{~d}$ & $7.54(1 \mathrm{H}, \mathrm{t}, J=7.0 \mathrm{~Hz})$ \\
\hline $\mathrm{C}=\mathrm{O}$ & $195.3 \mathrm{~s}$ & & $196.7 \mathrm{~s}$ & \\
\hline $3,5-\mathrm{CH}_{3}$ & & & $9.9 \mathrm{q}$ & $2.00(6 \mathrm{H}, \mathrm{s})$ \\
\hline \multicolumn{5}{|l|}{ Glucosyl } \\
\hline $1^{\prime \prime}$ & $100.5 \mathrm{~d}$ & $4.86(1 \mathrm{H}, \mathrm{d}, J=7.6 \mathrm{~Hz})$ & $104.2 \mathrm{~d}$ & $4.63(1 \mathrm{H}, \mathrm{d}, J=8.5 \mathrm{~Hz})$ \\
\hline $2^{\prime \prime}$ & $73.0 \mathrm{~d}$ & $3.15(1 \mathrm{H}, \mathrm{m})$ & $74.2 \mathrm{~d}$ & $3.36(1 \mathrm{H}, \mathrm{m})$ \\
\hline $3^{\prime \prime}$ & $76.1 \mathrm{~d}$ & $3.20(1 \mathrm{H}, \mathrm{m})$ & $76.1 \mathrm{~d}$ & $3.30(1 \mathrm{H}, \mathrm{m})$ \\
\hline $4^{\prime \prime}$ & $68.9 \mathrm{~d}$ & $3.50(1 \mathrm{H}, \mathrm{m})$ & $69.3 \mathrm{~d}$ & $3.44(1 \mathrm{H}, \mathrm{m})$ \\
\hline $5^{\prime \prime}$ & $73.6 \mathrm{~d}$ & $3.30(1 \mathrm{H}, \mathrm{m})$ & $73.5 \mathrm{~d}$ & $3.42(1 \mathrm{H}, \mathrm{m})$ \\
\hline $6^{\prime \prime}$ & $62.5 \mathrm{t}$ & $4.39(2 \mathrm{H}, \mathrm{br} \mathrm{s})$ & $62.7 \mathrm{t}$ & $\begin{array}{l}4.23(1 \mathrm{H}, \mathrm{d}, J=11.0,3.0 \mathrm{~Hz}) \\
4.32(1 \mathrm{H}, \mathrm{d}, J=11.0 \mathrm{~Hz})\end{array}$ \\
\hline \multicolumn{5}{|l|}{ Galloyl } \\
\hline $1^{\prime \prime \prime}$ & $119.2 \mathrm{~s}$ & & $119.6 \mathrm{~s}$ & \\
\hline $2^{\prime \prime \prime}, 6^{\prime \prime \prime}$ & $108.6 \mathrm{~d}$ & $6.98(2 \mathrm{H}, \mathrm{s})$ & $108.5 \mathrm{~d}$ & $6.96(2 \mathrm{H}, \mathrm{s})$ \\
\hline $3^{\prime \prime \prime}, 5^{\prime \prime \prime}$ & $145.4 \mathrm{~s}$ & & $145.3 \mathrm{~s}$ & \\
\hline $4^{\prime \prime \prime}$ & $138.4 \mathrm{~s}$ & & $138.3 \mathrm{~s}$ & \\
\hline $\mathrm{C}=\mathrm{O}$ & $165.7 \mathrm{~s}$ & & $165.6 \mathrm{~s}$ & \\
\hline
\end{tabular}

${ }^{1} \mathrm{H}-\mathrm{NMR}(600 \mathrm{MHz})$ and ${ }^{13} \mathrm{C}-\mathrm{NMR}(150 \mathrm{MHz})$ spectra were measured in DMSO- $d_{6}$ with TMS as internal standard 


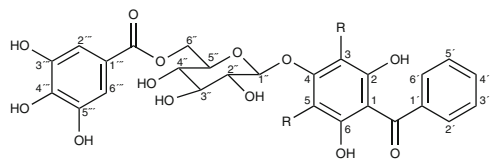

$1 \mathrm{R}=\mathrm{H}$

$2 \mathrm{R}=\mathrm{CH}_{3}$

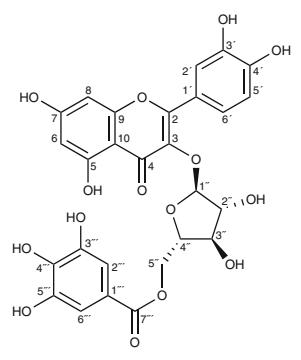

3
Fig. 1 Structures of guavinosides A (1), B (2), and C (3)
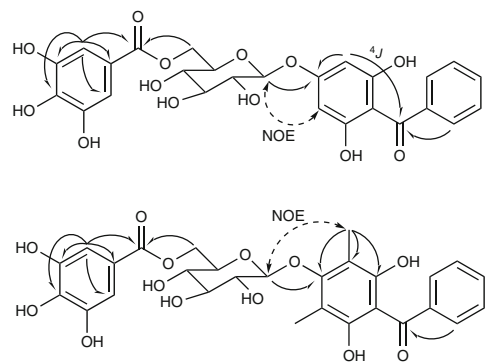

Fig. 2 Key HMBC and NOE correlations of guavinosides A (1) and B (2)

absence of the aromatic methine signal $\left[\delta_{\mathrm{H}} 6.11(\mathrm{~s}) ; \delta_{\mathrm{C}}\right.$ $94.9]$ in 1 , and a new aryl methyl signal $\left[\delta_{\mathrm{H}} 2.00(6 \mathrm{H}, \mathrm{s})\right.$; $\left.\delta_{\mathrm{C}} 9.9\right]$ and a quaternary carbon $\left(\delta_{\mathrm{C}} 110.8\right)$ were observed. In the ${ }^{13} \mathrm{C}$-NMR spectrum, the appearance of a high-field region shifted methyl signal suggested that the methyl is linked to a benzene ring in the ortho-position and attached via an oxygen atom [9]. HMBC correlations were observed from the methyl proton signal to $\delta_{\mathrm{C}} 110.8(\mathrm{C}-3,5), 151.8$ (C-2, 6), and 155.6 (C-4). NOE enhancement was also observed between the methyls and an anomeric proton at $\delta_{\mathrm{H}}$ 4.63. These data suggested that the aglycone of $\mathbf{2}$ was 2,4,6-trihydroxy-3,5-dimethylbenzophenone. Absolute configuration of the glucose moiety was determined to be $\mathrm{D}$ by using HPLC analysis with an OR detector. From the above data, the structure of $\mathbf{2}$ was identified to be 2,4,6trihydroxy-3,5-dimethylbenzophenone 4-O-(6" $-O$-galloyl)$\beta$-D-glucopyranoside.

Guavinoside C (3) was obtained as a yellow powder. Its HR-FAB-MS showed a quasimolecular ion peak at $\mathrm{m} / \mathrm{z}$ 585.0868 , corresponding to the molecular formula $\mathrm{C}_{27} \mathrm{H}_{22} \mathrm{O}_{15}$. The UV absorbances at 211, 265, and $355 \mathrm{~nm}$ were characteristic of flavonol. The IR spectrum indicated the presence of hydroxyl $\left(3,400 \mathrm{~cm}^{-1}\right)$, ester $\left(1,710 \mathrm{~cm}^{-1}\right)$, and conjugated carbonyl group $\left(1,690 \mathrm{~cm}^{-1}\right)$. In the ${ }^{1} \mathrm{H}$ NMR spectrum, meta-coupled signals at $\delta_{\mathrm{H}} 6.20$ and $\delta_{\mathrm{H}}$ 6.41 and a hydrogen-bonded hydroxyl signal at $\delta_{\mathrm{H}} 12.62$ indicated the presence of a 5,7-dihydroxy A ring system in flavonol. A spin system of three aromatic signals at $\delta_{\mathrm{H}} 7.46$
$(1 \mathrm{H}, \mathrm{d}, J=2.2 \mathrm{~Hz}), \delta_{\mathrm{H}} 6.85(1 \mathrm{H}, \mathrm{d}, J=8.8 \mathrm{~Hz})$, and $\delta_{\mathrm{H}}$ $7.49(1 \mathrm{H}, \mathrm{dd}, J=8.8,2.2 \mathrm{~Hz})$ indicated the presence of a $3^{\prime}, 4^{\prime}$-dihydroxy $\mathrm{B}$ ring system in flavonol. In the ${ }^{13} \mathrm{C}-\mathrm{NMR}$ spectrum, significant flavonol signals at $\delta_{\mathrm{C}} 157.3(\mathrm{C}-2)$, 133.0 (C-3), and $177.4(\mathrm{C}-4)$ were observed. In the HMBC experiment, the correlations from $2^{\prime}-\mathrm{H}$ to $\mathrm{C}-2, \delta_{\mathrm{C}} 144.9$ (C$\left.3^{\prime}\right), 148.3\left(\mathrm{C}-4^{\prime}\right)$, and $121.3\left(\mathrm{C}-6^{\prime}\right)$, from $6^{\prime}-\mathrm{H}$ to $\mathrm{C}-2, \mathrm{C}-4^{\prime}$ and $\delta_{\mathrm{C}} 115.6\left(\mathrm{C}-2^{\prime}\right)$, and from $5^{\prime}-\mathrm{H}$ to $\mathrm{C}-3^{\prime}, \mathrm{C}-4^{\prime}$, and $\delta_{\mathrm{C}}$ $120.8\left(\mathrm{C}-1^{\prime}\right)$ were observed. From these data, the aglycone of $\mathbf{3}$ was determined to be quercetin. In addition, an aromatic methine $\left(\delta_{\mathrm{H}} 6.89,2 \mathrm{H}, \mathrm{s}\right)$ correlated with $\delta_{\mathrm{C}} 118.9$ (C$\left.1^{\prime \prime \prime}\right), 108.5$ (C-2'"', 6"' $), 145.3\left(\mathrm{C}-3^{\prime \prime \prime}, 5^{\prime \prime \prime}\right), 138.4\left(\mathrm{C}-4^{\prime \prime \prime}\right)$, and 165.4 (carbonyl), indicating the presence of a galloyl moiety the same as $\mathbf{1}$ and $\mathbf{2}$. Acid hydrolysis of $\mathbf{3}$ with $2 \mathrm{M}$ $\mathrm{HCl}$ afforded (+)-L-arabinose that was identical by HPLC analysis using OR detector comparison to an authentic sample of L-arabinose. The small coupling constant of the anomeric proton $\left(\delta_{\mathrm{H}} 5.56, \mathrm{~d}, J=1.4 \mathrm{~Hz}\right)$ indicated the presence of the $\alpha$-form of arabinose. Correlations in the ${ }^{1} \mathrm{H}-{ }^{1} \mathrm{H}$ COSY spectrum were observed for a spin system from the anomeric signal to three oxymethine signals at $\delta_{\mathrm{H}}$ 4.18 (br s, 2"-H), $3.81\left(\mathrm{~m}, 3^{\prime \prime}-\mathrm{H}\right)$, and $3.74\left(\mathrm{~m}, 4^{\prime \prime}-\mathrm{H}\right)$, and methylene signals $\left(\delta_{\mathrm{H}} 4.11\right.$ and $\left.4.02,5^{\prime \prime}-\mathrm{H}_{2}\right)$ was observed. Furthermore, two hydroxy signals at $\delta_{\mathrm{H}} 5.72$ (br s) and 5.48 (br s) both coupled with $2^{\prime \prime}-\mathrm{H}$ and $3^{\prime \prime}-\mathrm{H}$, respectively. Additionally, the signals of $5^{\prime \prime}-\mathrm{H}_{2}$ of 3 were shifted downfield compared with those of $4\left(\delta_{\mathrm{H}} 3.36\right.$ and 3.32), and correlated with a galloyl carbonyl carbon signal in the HMBC experiment. From these observations, the sugar moiety was determined to be $\mathrm{L}-\alpha$-arabinofuranose. Thus, the structure of 3 was determined to be quercetin 3-O- $\left(5^{\prime \prime}-\right.$ $O$-galloyl)- $\alpha$-L-arabinofuranoside.

The structures of 4-8 were elucidated to be quercetin 3$O-\alpha$-L-arabinofuranoside (4), quercetin $3-O-\alpha$-L-arabinopyranoside (5), quercetin 3-O- $\beta$-D-xylopyranoside (6), quercetin 3-O- $\beta$-D-galactopyranoside (7), and quercetin 3$O$ - $\beta$-D-glucopyranoside (8) by comparison with spectroscopic data $[10,11]$ and chemical degradation methods.

Benzophenone glycosides have been isolated from many kind of plants, but this is first reported isolation of a dimethylbenzophene glycoside from a natural source. The substitution pattern is the well-known A ring of flavonoid; a possible biosynthesis pathway to the aglycone moiety of 2 would be methylation of the benzophenone skeleton.

Isolated compounds were evaluated for inhibitory activities against histamine release from rat peripheral mast cells [12] and nitric oxide (NO) production from a murine macrophage-like cell line, RAW264.7 cells [13]. Compounds 3-8 (at $100 \mu \mathrm{g} / \mathrm{ml}$ ) inhibited histamine release from mast cells with inhibition ratios of 94.4, 21.9, 30.5, 23.9, 100, and 93.5\%, respectively. But $\mathbf{1}$ and $\mathbf{2}$ did not show inhibitory activity against histamine release at this concentration. Compounds 3-8 (at $100 \mu \mathrm{g} / \mathrm{ml}$ ) inhibited 
NO production by RAW 264.7 cells stimulated with lipopolysaccharide and interferon gamma with inhibition ratios of 50.0, 33.2, 32.4, 65.1, 55.3, and 52.1\%, respectively. The isolated compounds therefore inhibited chemical mediators, such as histamine and NO, and increased IL-12 release from RAW 264.7 cells.

In conclusion, phenolic compounds isolated from $P$. guajava might be valuable candidates for treating various inflammatory diseases.

\section{Experimental}

General

The UV spectra were recorded on a Shimadzu model UV160 spectrophotometer. IR spectra were recorded on a Horiba FT-210 diffraction infrared spectrometer. FAB-MS were obtained with a JEOL model JMS-AX505 HA spectrometer. ${ }^{1} \mathrm{H}-\mathrm{NMR}(600 \mathrm{MHz})$ and ${ }^{13} \mathrm{C}-\mathrm{NMR}(150 \mathrm{MHz})$ spectra were obtained on a Varian Inova ${ }^{\mathrm{TM}} 600$ spectrometer and a JEOL Delta 600 spectrometer. NMR spectra were measured in DMSO- $d_{6}$ with TMS as internal standard. Optical rotation was measured with a Jasco DIP-370 polarimeter. The inhibitory activities against histamine release from rat mast cells and NO production were carried out as described in the literature method [14].

\section{Plant material}

Leaves of $P$. guajava were donated by OS Industrial Co. Ltd. (Tokyo, Japan).

\section{Extraction and isolation}

The dried leaves of $P$. guajava $(5 \mathrm{~kg})$ were extracted with 151 of $80 \% \mathrm{MeOH}$ at room temperature for 7 days. The solution was filtered and concentrated under reduced pressure to give a crude extract. The extract was dissolved in water and passed through a Diaion HP-20 column (Mitsubishi Kasei, Tokyo, Japan), and eluted stepwise with 50, 70, and $100 \% \mathrm{MeOH}$. The $70 \% \mathrm{MeOH}$ eluate was dissolved in EtOH and passed through a Sephadex LH-20 column (Pharmacia, Uppsala, Sweden). The effluent was chromatographed on a Diaion CHP-20P column (Mitsubishi Kasei, Tokyo, Japan), and eluted with 50 and $70 \%$ $\mathrm{MeOH}$. All fractions were monitored by TLC, and the fractions containing the same compound(s) (as evidenced by TLC) were combined to give four fractions. Fraction 3 (900 mg) was chromatographed on a Sephadex LH 20 column developed with $\mathrm{CHCl}_{3}-\mathrm{MeOH}$ (1:1) to give four fractions. Fraction $2(770 \mathrm{mg})$ was further applied to a reversed-phase column (SSC ODS, Senshu Scientific Co.
Ltd., Tokyo, Japan) eluted stepwise with $0-25 \% \mathrm{MeOH}$, and recrystallized from $\mathrm{MeOH}$ to give $\mathbf{1}(47 \mathrm{mg})$. Fraction $4(124 \mathrm{mg}$ ) was purified by medium pressure liquid chromatography (Yamazen Baker-bond ODS Yamazen, Kyoto, Japan) column eluted with $\mathrm{MeCN}-\mathrm{MeOH}-\mathrm{H}_{2} \mathrm{O}$ (5:35:60) to give $2(44 \mathrm{mg})$. Fraction $3(130 \mathrm{mg})$ was purified by reversed-phase HPLC [column: Shiseido Capcell pak C18 UG120 (10-mm i.d. $\times 250 \mathrm{~mm}$, Shiseido, Tokyo, Japan); mobile phase: $\mathrm{MeCN}-\mathrm{MeOH}-\mathrm{H}_{2} \mathrm{O}$ (5:30:65); flow rate: $3.0 \mathrm{ml} / \mathrm{min}$; detection: $\mathrm{UV}$ at $254 \mathrm{~nm}$ ] to give $3(14 \mathrm{mg})$. The $100 \% \mathrm{MeOH}$ eluate of Diaion HP-20 was dissolved in $\mathrm{MeOH}$, and chromatographed on a Sephadex LH-20 column $(2.5 \times 100 \mathrm{~cm})$ to give ten fractions. Fraction 3 $(1.9 \mathrm{~g})$ was chromatographed on a silica gel column developed with $\mathrm{CHCl}_{3}-\mathrm{MeOH}$ to give eight fractions. Fraction $6(515 \mathrm{mg})$ was purified by reversed-phase HPLC [column: Shiseido Capcell pak C18 UG120 (10-mm i.d. $\times 250 \mathrm{~mm}$ ); mobile phase: $\mathrm{MeCN}-\mathrm{H}_{2} \mathrm{O}$ (18:82); flow rate: $3.0 \mathrm{ml} / \mathrm{min}$.; detection: $\mathrm{UV}$ at $250 \mathrm{~nm}$ ] to give 4 (20 mg), 5 (50 mg), 6 (62 mg), 7 (62 mg), and 8 (30 mg), respectively.

Guavinoside A (1) was obtained as a yellow powder. $[\alpha]_{D}^{26}-114^{\circ} \quad(c=0.1, \quad \mathrm{MeOH}) ; \quad$ FAB-MS $\quad m / z \quad 545$ $(\mathrm{M}+\mathrm{H})^{+}$; HR-FAB-MS (found 545.8418, calcd for $\mathrm{C}_{26} \mathrm{H}_{25} \mathrm{O}_{13}$ : 545.8413); UV $\lambda_{\max }^{\mathrm{MeOH}} \mathrm{nm}(\varepsilon): 218(26,800)$, $288(16,200)$; IR $v_{\max }^{\mathrm{KBr}} \mathrm{cm}^{-1}: 3,390(\mathrm{OH}), 1,700$ (ester). ${ }^{1} \mathrm{H}-$ and ${ }^{13} \mathrm{C}$-NMR data, see Table 1.

Guavinoside B (2) was obtained as a yellow powder; $[\alpha]_{D}^{26}-83^{\circ}(c=0.5, \mathrm{MeOH})$; FAB-MS $m / z, 571(\mathrm{M}-$ $\mathrm{H})^{-}$; HR-FAB-MS (found 571.1474, calcd for $\mathrm{C}_{28} \mathrm{H}_{27} \mathrm{O}_{13}$ : 571.1451); UV $\lambda_{\text {max }}^{\mathrm{MeOH}} \mathrm{nm}(\varepsilon): 218(26,400), 283(15,100)$; IR $v_{\max }^{\mathrm{KBr}} \mathrm{cm}^{-1}: 3,410(\mathrm{OH}), 1,710$ (ester), 1,690 (C=O). ${ }^{1} \mathrm{H}-$ and ${ }^{13} \mathrm{C}$-NMR data, see Table 1.

Guavinoside $\mathrm{C}(\mathbf{3})$ was obtained as a yellow powder; $[\alpha]_{D}^{26}-73^{\circ}(c=1.0, \mathrm{MeOH}) ;$ FAB-MS $m / z .585(\mathrm{M}-$ $\mathrm{H})^{-}$; HR-FAB-MS (found 585.0868, calcd for $\mathrm{C}_{27} \mathrm{H}_{21} \mathrm{O}_{15}$ : 585.0880); $\lambda_{\max }^{\mathrm{MeOH}} \mathrm{nm}(\varepsilon): 211(32,000), 265(16,200), 355$ $(10,000)$; IR $v_{\max }^{\mathrm{KBr}} \mathrm{cm}^{-1}: 3,400(\mathrm{OH}), 1,710$ (ester), 1,690 $(\mathrm{C}=\mathrm{O}) .{ }^{1} \mathrm{H}-$ and ${ }^{13} \mathrm{C}-\mathrm{NMR}$ data, see Table $2 .{ }^{1} \mathrm{H}-\mathrm{NMR}$ $(600 \mathrm{MHz})$ and ${ }^{13} \mathrm{C}$-NMR $(150 \mathrm{MHz})$ spectra were measured in DMSO- $d_{6}$ with TMS as internal standard

\section{Acid hydrolysis of 1-3}

Compound 1, 2, or 3 (3.0 mg, each) was treated with $0.5 \mathrm{ml}$ of $2 \mathrm{M} \mathrm{HCl}$ for $2 \mathrm{~h}$ at $110^{\circ} \mathrm{C}$ in a sealed tube. The reaction mixture was diluted with $1 \mathrm{ml}$ of $\mathrm{H}_{2} \mathrm{O}$, and extracted with an equal volume of EtOAc, and the water layer was evaporated to dryness. The residue was dissolved in $\mathrm{H}_{2} \mathrm{O}(200 \mu \mathrm{l})$ and subjected to HPLC analysis [column: Asahi pak NH2P-50, (4.6-mm i.d. $\times 250 \mathrm{~mm}$, Showa Denko, Tokyo, Japan); mobile phase: $\mathrm{MeCN}^{-} \mathrm{H}_{2} \mathrm{O}$ (75:25); flow rate: $1.0 \mathrm{ml} / \mathrm{min}$; detection: OR detector (Shodex 
Table $2{ }^{13} \mathrm{C}$ - and ${ }^{1} \mathrm{H}$-NMR spectral data of guavinoside C (3)

\begin{tabular}{|c|c|c|}
\hline No. & $\delta_{\mathrm{C}}$ & $\delta_{\mathrm{H}}$ \\
\hline 2 & $157.3 \mathrm{~s}$ & \\
\hline 3 & $133.0 \mathrm{~s}$ & \\
\hline 4 & $177.4 \mathrm{~s}$ & \\
\hline 5 & $161.9 \mathrm{~s}$ & \\
\hline 6 & $98.5 \mathrm{~d}$ & $6.20(1 \mathrm{H}, \mathrm{d}, J=1.5 \mathrm{~Hz})$ \\
\hline 7 & $164.1 \mathrm{~s}$ & \\
\hline 8 & $93.5 \mathrm{~d}$ & $6.41(1 \mathrm{H}, \mathrm{d}, J=1.5 \mathrm{~Hz})$ \\
\hline 9 & $156.3 \mathrm{~s}$ & \\
\hline 10 & $103.9 \mathrm{~s}$ & \\
\hline $1^{\prime}$ & $120.8 \mathrm{~s}$ & \\
\hline $2^{\prime}$ & $115.6 \mathrm{~d}$ & $7.46(1 \mathrm{H}, \mathrm{d}, J=2.2 \mathrm{~Hz})$ \\
\hline $3^{\prime}$ & $144.9 \mathrm{~s}$ & \\
\hline $4^{\prime}$ & $148.3 \mathrm{~s}$ & \\
\hline $5^{\prime}$ & $115.4 \mathrm{~d}$ & $6.85(1 \mathrm{H}, \mathrm{d}, J=8.8 \mathrm{~Hz})$ \\
\hline $6^{\prime}$ & $121.3 \mathrm{~d}$ & $7.49(1 \mathrm{H}, \mathrm{d}, J=8.8,2.2 \mathrm{~Hz})$ \\
\hline $5-\mathrm{OH}$ & & $12.62(1 \mathrm{H}, \mathrm{s})$ \\
\hline \multicolumn{3}{|c|}{ Arabinosyl } \\
\hline $1^{\prime \prime}$ & $107.7 \mathrm{~d}$ & $5.56(1 \mathrm{H}, J=1.4 \mathrm{~Hz})$ \\
\hline $2^{\prime \prime}$ & $81.7 \mathrm{~d}$ & $4.18(1 \mathrm{H}$, br s $)$ \\
\hline $3^{\prime \prime}$ & $76.9 \mathrm{~d}$ & $3.81(1 \mathrm{H}, \mathrm{m})$ \\
\hline $4^{\prime \prime}$ & $81.9 \mathrm{~d}$ & $3.74(1 \mathrm{H}, \mathrm{m})$ \\
\hline $5^{\prime \prime}$ & $62.5 \mathrm{t}$ & $\begin{array}{l}4.11(1 \mathrm{H}, \mathrm{dd}, J=12.0,3.3 \mathrm{~Hz}) \\
4.02(1 \mathrm{H}, \mathrm{dd}, J=12.0,5.8 \mathrm{~Hz})\end{array}$ \\
\hline $2^{\prime \prime}-\mathrm{OH}$ & & $5.72(1 \mathrm{H}, \mathrm{br} \mathrm{s})$ \\
\hline $3^{\prime \prime}-\mathrm{OH}$ & & $5.48(1 \mathrm{H}$, br s $)$ \\
\hline \multicolumn{3}{|l|}{ Galloyl } \\
\hline $1^{\prime \prime \prime}$ & $118.9 \mathrm{~s}$ & \\
\hline $2^{\prime \prime \prime}, 6^{\prime \prime \prime}$ & $108.5 \mathrm{~d}$ & $6.89(2 \mathrm{H}, \mathrm{s})$ \\
\hline $3^{\prime \prime \prime}, 5^{\prime \prime \prime}$ & $145.3 \mathrm{~s}$ & \\
\hline $4^{\prime \prime \prime}$ & $138.4 \mathrm{~s}$ & \\
\hline $\mathrm{C}=\mathrm{O}$ & $165.4 \mathrm{~s}$ & \\
\hline
\end{tabular}

OR-2, Showa Denko, Tokyo, Japan) and RI (Shodex RI-72, Showa Denko, Tokyo, Japan), column temperature: $\left.40^{\circ} \mathrm{C}\right]$. Retention time and optical rotation of these samples $(\mathbf{1}, \mathbf{2}$, and 3) were found to be $8.5 \mathrm{~min}$ (positive), $8.5 \mathrm{~min}$ (positive), and $6.0 \mathrm{~min}$ (positive), respectively. Retention time of standard samples of $(+)$-D-glucose, $(+)$-L-arabinose, $(-)$-D-arabinose, and (+)-D-xylose were found to be $8.5 \mathrm{~min}$ (positive), $6.0 \mathrm{~min}$ (positive), $6.0 \mathrm{~min}$ (negative), and $6.3 \mathrm{~min}$ (positive), respectively.

Acknowledgments This work was supported in part by a Grant-inAids from the Ministry of Health and Welfare of Japan (No. 19980070), by a Special Research Grant-in Aid for the development of characteristic education and High-Tech Research Centers from the Ministry of Education, Science, Sports and Culture of Japan to Nihon University, and by the Japan-China Medical Association, and
“Academic Frontier" Project for Private Universities matching fund subsidy from MEXT (Ministry of Education, Culture, Sports, Science and Technology) 2002-2007 and 2007-2010 of Japan.

Open Access This article is distributed under the terms of the Creative Commons Attribution Noncommercial License which permits any noncommercial use, distribution, and reproduction in any medium, provided the original author(s) and source are credited.

\section{References}

1. Okuda T, Yoshida T, Hatano T, Yazaki K, Ashida M (1982) Ellagitannins of the casuarinaceae, stachyurqaceae and myrtaceae. Phytochemistry 21:2871-2874

2. Okuda T, Yoshida T, Hatano T, Yazaki K, Ikegami Y, Shingu T (1987) Guavins A, C and D, complex tannins from Psidium guajava. Chem Pharm Bull 35:443-446

3. Okuda T, Hatano T, Yazaki K (1984) Guavin B, an ellagitannin of novel type. Chem Pharm Bull 32:3787-3788

4. Lozoya X, Meckes M, Abou-zaid M, Tortoriello J, Nozzolillo C, Arnason JT (1994) Quercetin glycosides in Psidium guajava L. leaves and determination of a spasmolytic principle. Arch Med Res 25:11-15

5. Morales MM, Tortoriello J, Meckes M, Paz D, Lozoya X (1994) Calcium-antagonist effect of quercetin and its relation with the spasmolytic propaties of Psidium gujava L. Arch Med Res 25:17-21

6. Osman AM, Younes M, Garby EL, Sheta AE (1974) Chemical examination of local plants. VI. Triterpenoids of the leaves of Psidium guajava. Phytochemistry 13:2015-2016

7. Smith RM, Siwatibau S (1975) Aeaquiterpene hydrocarbons of Fijian guavas. Phytochemistry 14:2013-2015

8. Mercadantre AZ, Steck A, Pfander H (1999) Carotenoids from Guava (Psidium guajava L.): isolation and structure elucidation. J Agric Food Chem 47:145-151

9. Matsuzaki K, Tahara H, Inokoshi J, Tanaka H, Masuma R, Omura S (1998) New brominated and halogen-less derivatives and structure-activity relationship of azaphilones inhibiting gp120-CD4 binding. J Antibiot 51:1004-1011

10. Markharm KR, Chari VM (1982) Carbon-13 NMR spectroscopy of flavonoids. In: Harnorne JB, Mabry TJ (eds) The flavonoids: advances in research. Chapman \& Hall, London, pp 19-51

11. Markharm KR, Geiger H (1994) ${ }^{1} \mathrm{H}$ nuclear magnetic resonance spectroscopy of flavonoids and their glycosides in hexadeutero dimethylsulfoxide. In: Harnorne JB (ed) The flavonoids, advances in research since 1986. Chapman \& Hall, London, pp 441471

12. Kitanaka S, Nakayama T, Shibano T, Ohkoshi E, Takido M (1998) Antiallergic agent from natural sources. Structures and inhibitory effect of histamine release of naphthopyrone glycosides from seeds of Cassia obtusifolia L. Chem Pharm Bull 46:1650-1652

13. Wang J, Matsuzaki K, Kitanaka S (2007) Antiallergic agents from natural sources. Part 19. Stilbene derivatives from Pholidota chinensis and their antiinflammatory activity. Chem Pharm Bull 54:1216-1218

14. Wang J, Wang N, Yao X, Ishii R, Kitanaka S (2006) Inhibitory activity of Chinese herbal medicines toward histamine release from mast cells and nitric oxide production by macrophage-like cell line, RAW 264.7. J Nat Med 60:73-77 